\title{
16. MINERALOGICAL AND GEOCHEMICAL INVESTIGATIONS OF SEDIMENTS ON THE MAZAGAN PLATEAU, NORTHWESTERN AFRICAN MARGIN (LEG 79, DEEP SEA DRILLING PROJECT) ${ }^{1}$
}

\author{
Hervé Chamley and Pierre Debrabant, Université de Lille I ${ }^{2}$
}

\begin{abstract}
Detailed mineralogical and geochemical studies were performed on samples from selected time intervals recovered during Leg 79 on the Mazagan Plateau. The uppermost Albian and Cenomanian sediments of Sites 545 and 547 can be correlated on the basis of mineralogy and geochemistry; these sediments illustrate differential settling processes and the existence of hot climates with alternating humid and dry seasons in the African coastal zone. The upper Aptian to Albian black shales of Site 545 point to an irregular alternation of tectonic activity and relaxation stages, allowing different behaviors in the reworking of soils, crystalline rocks, and sediments born in peri-marine basins. The barren lower Mesozoic reddish sediments and evaporitic series of Sites 546 and 547 are characterized by a strong physical erosion of sialic landscapes, without clear evidence of post-depositional metamorphic events. At Site 546 strong early diagenetic processes in a confined evaporitic environment affect both the mineralogy and the geochemistry of pre-Miocene rocks.
\end{abstract}

\section{INTRODUCTION}

Mineralogical and geochemical investigations have been made on selected lithofacies representing specific time intervals, from sedimentary materials of Sites 545,546 , and 547 of the Deep Sea Drilling Project Leg 79, on the slope of the Mazagan Plateau, off Morocco. The Mesozoic carbonate platform in this area is structurally controlled by either diapiric structures or sialic basement (Fig. 1) (site chapters, this volume). The aim of the study was to obtain information on the stratigraphy, paleoenvironment, and diagenetic evolution of the sediments. Detailed studies have been made on the upper Albian to Cenomanian green nannofossil claystone recovered at Sites 545 and 547 and on the lower Mesozoic red clays, halite, and associated facies encountered in cores from Sites 546 and 547 . We also have investigated samples of upper Aptian to Albian sediments from Site 545, and Cenozoic clayey to calcareous oozes from Site 547. Table 1 summarizes the sites studied.

\section{ANALYTICAL PROCEDURES}

The X-ray diffraction method was as follows. The samples were dissociated in water, then calcium carbonate was removed in $5 \mathrm{~N}$ hydrochloric acid. Excess acid was removed by successive centrifuging; deflocculation was improved using a microhomogenizer. The fraction smaller than $2 \mu \mathrm{m}$ was collected by decantation, following settling times determined by using Stokes' law; then oriented pastes were made on glass slides. A Philips Model 1730 diffractometer (copper radiation) was used to make the X-ray diffraction scans at $2^{\circ} 2 \theta / m i n$. Three diffractograms were made (1) from $2.5^{\circ}$ to $28.5^{\circ} \Theta$ on natural samples; (2) from $2.5^{\circ}$ to $14.5^{\circ} \theta$ on glycolated samples; (3) from $2.5^{\circ}$ to $14.5^{\circ}$ $2 \theta$ on samples heated for 2 hours at $490^{\circ} \mathrm{C}$. The quantitative evaluations obtained are based on peak heights and areas (Chamley, 1979). The heights of illite and chlorite 001 peaks (diagram for glycolated sample) were taken as references. By comparison with these values, values for smectite, palygorskite, sepiolite, vermiculite, and irregular

\footnotetext{
${ }^{1}$ Hinz, K., Winterer, E. L., et al., Init. Repts. DSDP, 79: Washington (U.S. Govt. Printing Office),

2 Address: Sédimentologie et Géochemie. ERA 764 CNRS, Université de Lille I, 59655 Villeneuve d'Ascq, France.
}

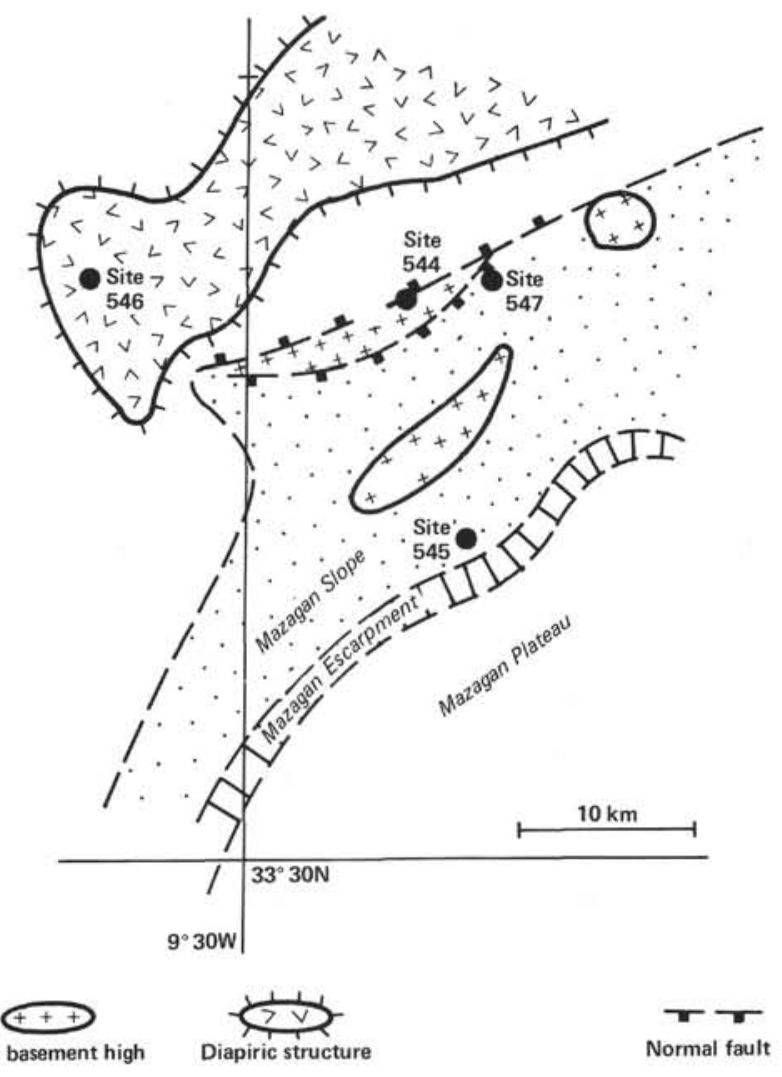

Figure 1. Location of Leg 79 sites.

mixed-layer clays were corrected by addition of peak height ( $x$ $1.5-2.0$ according to the crystallinity of each species), whereas values for well-crystallized kaolinite were corrected by subtraction $(\times 0.7-$ 0.5 , depending on kaolinite crystallinity). The relative proportions of chlorite and kaolinite were determined from the ratio of the heights of the 3.54 and $3.57^{\circ} \AA$ peaks, respectively. When this ratio is 1 , the amount of chlorite is assumed to be twice that of kaolinite. Data are given in percentages, the relative error is estimated at $\pm 5 \%$. Additional data concern the bulk mineralogy obtained by X-ray diffraction on randomly oriented powders. 
Table 1. Site summaries.

\begin{tabular}{|c|c|c|c|c|c|}
\hline Site & Location & $\begin{array}{l}\text { Water depth } \\
\text { (m) }\end{array}$ & $\begin{array}{l}\text { Penetration } \\
\text { (m) }\end{array}$ & $\begin{array}{c}\text { Nature of } \\
\text { bottom sampled }\end{array}$ & $\begin{array}{l}\text { Age and number } \\
\text { of samples }\end{array}$ \\
\hline 544 & $\begin{array}{l}33^{\circ} 46.00^{\prime} \mathrm{N} \\
09^{\circ} 24.26^{\prime} \mathrm{W}\end{array}$ & 3607 & 235 & Gneiss & early Mesozoic 3 \\
\hline 545 & $\begin{array}{l}33^{\circ} 39.86^{\prime} \mathrm{N} \\
09^{\circ} 21.88^{\prime} \mathrm{W}\end{array}$ & 3150 & 701 & Dolomite & $\begin{array}{l}\text { late Aptian to } \\
\text { Cenomanian } 25\end{array}$ \\
\hline 546 & $\begin{array}{l}33^{\circ} 46.07^{\prime} \mathrm{N} \\
09^{\circ} 33.09^{\prime} \mathrm{W}\end{array}$ & 3992 & 129 & Halite & early Mesozoic 27 \\
\hline 547 & $\begin{array}{l}33^{\circ} 46.08^{\prime} \mathrm{N} \\
09^{\circ} 21.00^{\prime} \mathrm{W}\end{array}$ & 3940.5 & 1030 & Mudstone & $\begin{array}{l}\text { Pliocene, Paleocene } 6 \\
\text { Albo-Cenomanian } 39 \\
\text { early Mesozoic } 14\end{array}$ \\
\hline
\end{tabular}

Electron-microscopy observations were made with a Siemens transmission microscope, on less than $8 \mu \mathrm{m}$ particles deposited on copper grids covered by a collodion film after carbonate removal and physical deflocculation.

The geochemical procedure was the following: The samples were dried at $105^{\circ} \mathrm{C}$, crushed, and homogenized. Then $0.2 \mathrm{~g}$ was subjected to alkaline fusion, solubilized by $\mathrm{HCl}$, diluted to $100 \mathrm{ml}$, and treated fluoronitrically in a bomb at $150^{\circ} \mathrm{C}$ and 50 bars for $\mathrm{SiO}_{2}$ and $\mathrm{Al}_{2} \mathrm{O}_{3}$ determination. Also, $1 \mathrm{~g}$ was subjected to fluoroperchloric treatment, solubilized by $\mathrm{HCl}$, and diluted to $100 \mathrm{ml}$. The dilutions were used for colorimetric analysis of $\mathrm{TiO}_{2}$ and $\mathrm{P}_{2} \mathrm{O}_{5}$ and for spectrophotometric determination of other major and trace elements by atomic absorption analysis, using a Type 5000 Perkin Elmer automated spectrophotometer. The reproductibility of the measurements is $\pm 3 \%$ for major elements, $\pm 10 \%$ for trace elements.

\section{LATE CRETACEOUS TO EARLIEST PALEOCENE}

The Upper Cretaceous to lowest Paleocene claystones to marlstones of Hole 547A (Cores 32A-38A) are marked by abundant smectite $(80 \%)$ accompanied by palygorskite $(10 \%)$, illite $(5 \%)$, and little amounts of sepiolite, chlority, and irregular mixed layers. Such an assemblage is well known during this period, especially in the earliest Paleogene of The northeastern Atlantic, and is considered as reflecting hot and humidity-contrasted climate on adjacent landmasses (Mélières, 1978; Chamley, 1979).

\section{LATE ALBIAN AND CENOMANIAN, SITES 545 AND 547}

Upper Albian to Cenomanian deposits of Site 547 consist of nannofossil claystone to mudstone with intraformational clay pebble structures and slump structures (Cores 547B-5 to 547B-2, 547A-73 to $547 \mathrm{~A}-39,350 \mathrm{~m}$ thickness), while those of Site 545 consist of green nannofossil claystone with some slump structures (approximately Cores 545-40 to 545-29, $124 \mathrm{~m}$ thickness (Fig. 2). In spite of these differences, the clay mineralogy and bulk geochemistry are fairly similar at both sites. Smectite is very abundant (50-90\% of clay minerals) and is associated with kaolinite (5-25\%), palygorskite (traces to rarely $45 \%$ ), illite (traces to $10 \%$ ), chlorite and irregular mixed-layer clays (traces), quartz (common), and opal-CT (rare) (Plate 1, Figs. 1-4). These mineralogical similarities suggest a comparable origin for the different species in both sites. A predominantly detrital origin for the clay assemblages is interpreted based on previous studies on the Moroccan margin and in the whole North Atlantic Basin (Mélières, 1978); Chamley, 1979; CEPM, 1980; Chamley et al., 1980) and also is supported by the extent of resedimentation structures, high sedimentation rates, and absence of correlation between detailed li- thology and clay mineralogy. The abundance of $\mathrm{Al}-\mathrm{Fe}$ smectites and kaolinite indicates the probable importance of pedogenic processes on the landmasses and the existence of hot climates with alternating wet and dry seasons (Chamley, 1979). The data from Leg 79 agree well with those from Legs $41,47,48$, and 50 from the eastern North Atlantic.

The inorganic geochemistry changes moderately with depth in the sedimentary column, and the variations observed depend chiefly on the variations of the $\mathrm{CaCO}_{3}$ content (13-65\%). Metalliferous accumulations do not occur (Figs. 3, 4): the detrital character of the sedimentation (parameter D) dominates everywhere; the absence of manganese precipitation (parameter $\mathrm{Mn}^{*}$ ) indicates a reduced environment and a high sedimentation rate (Debrabant and Foulon, 1979). The aluminoferrous characteristic of geochemical parameters results from the presence in noticeable amounts of smectite $(\mathrm{Fe})$ and kaolinite $(\mathrm{Al})$.

In spite of this general homogeneity, minor but significant mineralogical and geochemical changes occur with depth in the sedimentary column and permit stratigraphic correlations between Sites 547 and 545 (Fig. 2, Table 2).

The most important break occurs in the latest Albian, close to the Albian/Cenomanian boundary (Cores 547A-66 to 547A-64; Cores 545-38 to 545-37). It corresponds to a significant decrease of illite, palygorskite, potassium, magnesium, and phosphorus and a correlative increase of smectite, kaolinite, aluminum, and iron (Fig. 2 and 5; see also Table 3). The good correlation existing in both Sites 547 and 545 for the late Albian and latest Albian-Cenomanian time intervals is clearly summarized in Figure 3, which shows the respective abundances of $\mathrm{Al}_{2} \mathrm{O}_{3}$ and $\mathrm{MgO}$. Additional differences between both time intervals can be observed in Sites 545 and 547 (Figs. 3 and 4), namely a decrease of $\mathrm{CaO}$ and an increase of $10^{3} \mathrm{Sr} / \mathrm{CaO}$ at the late Albian/latest Albian boundary, which probably indicate a selective dissolution of calcite in a reducing diagenetic environment (Maillot and Robert, 1980) and the transfer of strontium from carbonates to smectites.

The general inorganic stratigraphy reported here could be useful in order to support the biostratigraphical scale in a depositional environment characterized by noticeable dissolution processes and by sedimentary reworking.

Significant lateral changes also occur if comparing the clay mineralogy of Sites 547 and 545 (Fig. 2).

\begin{tabular}{lcc}
\hline & Site 545 & Site 547 \\
\hline Illite & tr-10\% & tr-5\% \\
Smectite & $60-75 \%$ & $65-90 \%$ \\
Kaolinite & $15-25 \%$ & $10-20 \%$ \\
Palygorskite & tr-10\% & tr-5\% \\
& (maximum 45\%) & (maximum 35\%) \\
\hline
\end{tabular}

Smectite is more abundant at Site 547. As deduced from previous studies (Millot, 1964; Chamley, 1979), smectite appears to originate chiefly from the reworking of coastal soils and surficial coastal sediments, while other 


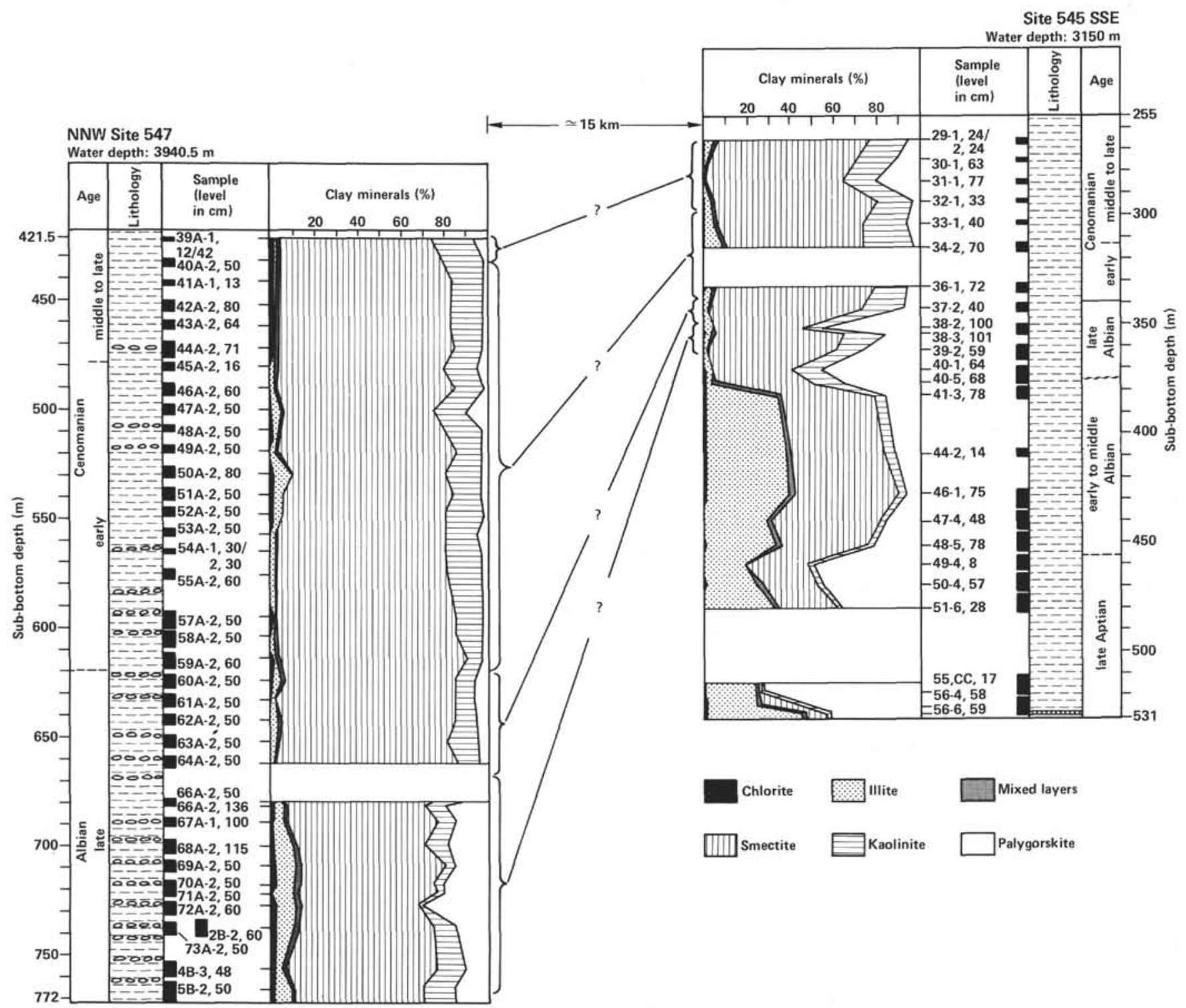

Figure 2. Cretaceous clay stratigraphy and tentative mineralogical correlations, Sites 545 and 547. A and B indicate Holes 547A and 547B. For updated biostratigraphic correlations see chapters by Leckie (this volume) and Wiegand (this volume).

minerals are mainly reworked from various rocks (illite, palygorskite) and upstream soils (kaolinite). Smectite is well known in modern marine environments for its ability to settle later than other minerals, especially illite and kaolinite (Whitehouse et al., 1960; Gibbs, 1977). Thus, it is suggested that during the mid Cretaceous differential settling processes occurred off the northwestern African margin. These processes determined the preferential sedimentation of illite and associated minerals at Site 545, which is located at the foot of the Mazagan Escarpment, and the preferential sedimentation of smectite at Site 547 located more distally. The parallel mineralogical variations recorded at both sites indicate a more proximal situation for Site 545 favoring supply from rock and soil products, a more distal situation for Site 547 , favoring supplies from soil products downstream.

\section{LATE APTIAN TO MIDDLE ALBIAN, SITE 545}

The lower part of Site 545 Cretaceous green nannofossil claystones (Unit III) represents the late Aptian to middle Albian (Cores 545-56 to 545-41 approximately). This sequence is characterized by slump structures, microfaults, and low-angle slide surfaces, pointing to resedimentation processes (site chapter, this volume). Illite, smectite, and palygorskite are the three major clay minerals, the relative proportions of each increase or decrease independently of the lithology or the depth of burial. Three major palygorskite peaks are apparent, marked by abundant bundles of well-preserved fibers in the sediments (Plate 2, Figs. 1, 2) and by high $\mathrm{MgO} /$ $\mathrm{Al}_{2} \mathrm{O}_{3}$ ratios. In some intervals the three clay minerals are present in comparable abundances (Plate 1, Figs. 5, 


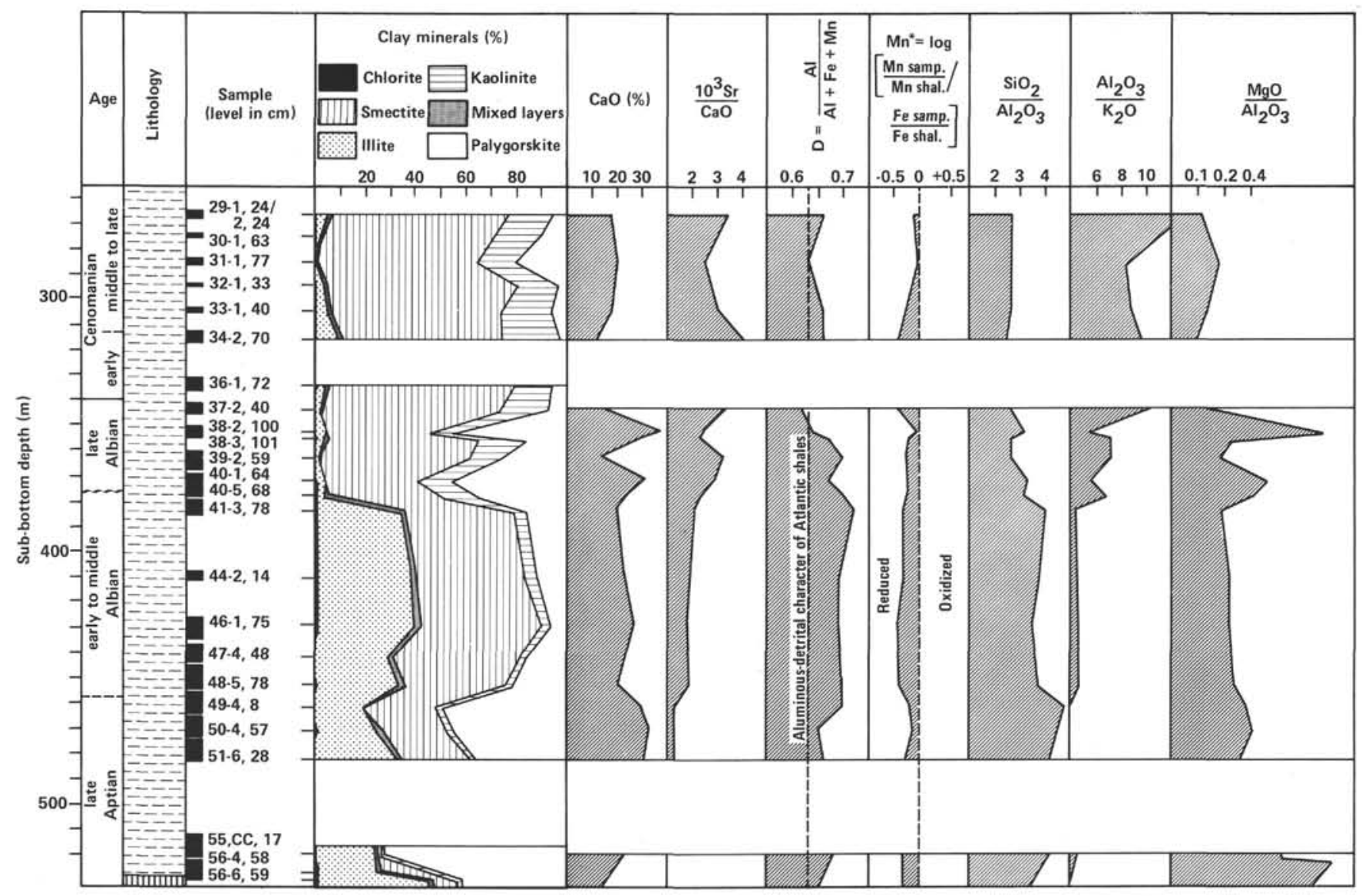

Figure 3. Cretaceous clay mineralogy and bulk geochemistry, Site 545 .

6). Illite-rich levels correspond to low $\mathrm{Al}_{2} \mathrm{O}_{3} / \mathrm{K}_{2} \mathrm{O}$ ratios. A strongly reduced character (Index $\mathrm{Mn}^{*}<0$ ) occurs in the deposition environment, as well as a highly aluminous-detrital influence (D close to 0.7, Fig. 3). Slight phosphate concentrations appear at Sample 545-56-6, $59 \mathrm{~cm}$ (also magnesian rich and strontium poor) and Sample $545-44-3,78 \mathrm{~cm}$, suggesting temporary lower sedimentation rates. Occasional tectonic activity along the Moroccan continental margin during this time period may be responsible for higher sedimentation rates and the combined reworking of continental soils (smectite), or continental rocks especially from peri-marine basins (palygorskite), and of various marine sediments (i.e., Chamley, 1979). A major break occurs in Core 545-40: the decrease of illite and potassium, the increase of aluminoferrous smectites, and the presence of phosphates suggest lower sedimentation rates, the reworking of surficial continental formations (especially soils), and a tectonic relaxation during the late Albian and Cenomanian.

\section{EARLY MESOZOIC, SITES 546 AND 547}

Sediments of latest Triassic to earliest Jurassic age have been collected at Sites 546 and 547 (Figs. 6, 7). At Site 546 we have studied grayish red gypsiferous sandy clays (Cores 546-17 and 546-18, 149-156.5 m) where Miocene microfossils are mixed with Mesozoic elements, as well as halite banded with grayish red to grayish green and gray clayey streaks (Cores 546-18 and 546-20, 156.5-192 m). In Hole 547B we have considered the grayish red sandy mudstones, locally interbedded with dark gray sandy mudstones (Cores 547B-25 to 547B-34, 924-1030 m).

Sites 546 and 547 are characterized by the abundance of chlorite and illite in the clay fraction, with these being the only clay minerals in most sedimentary levels (Plate 2B, Figs. 3, 4). Quartz is ubiquitous. Dolomite, gypsum, and halite are frequent and are associated with relatively high amounts of $\mathrm{MgO}$ and frequently with $\mathrm{Na}_{2} \mathrm{O}$ or $\mathrm{K}_{20}$. Lithium is the most typical trace element and probably accompanies the micaceous minerals. The presence of a sialic basement very close to the bottom of Hole 547B suggests the possibility of strong erosional processes acting on a poorly weathered continental crust. Traces of irregular mixed-layer clays occur locally only: Samples 546-20, $141 \mathrm{~cm}$; 547B-34-2, $110 \mathrm{~cm}$; and $33-3,0 \mathrm{~cm}$. The rareness of chemical alteration products could be due to the importance of physical alteration effects on a high-relief continental area at the time of deposition. Another cause of the peculiar clay mineralogy observed could be the occurrence of epimetamorphic events after sediment deposition, as it has been shown in the Permo-Triassic of northern Morocco (Robillard and Piqué, 1981). But there is no lithologic or petrographic evidence of any metamorphic influences off the Moroccan margin, an area located far away from the tectoni- 


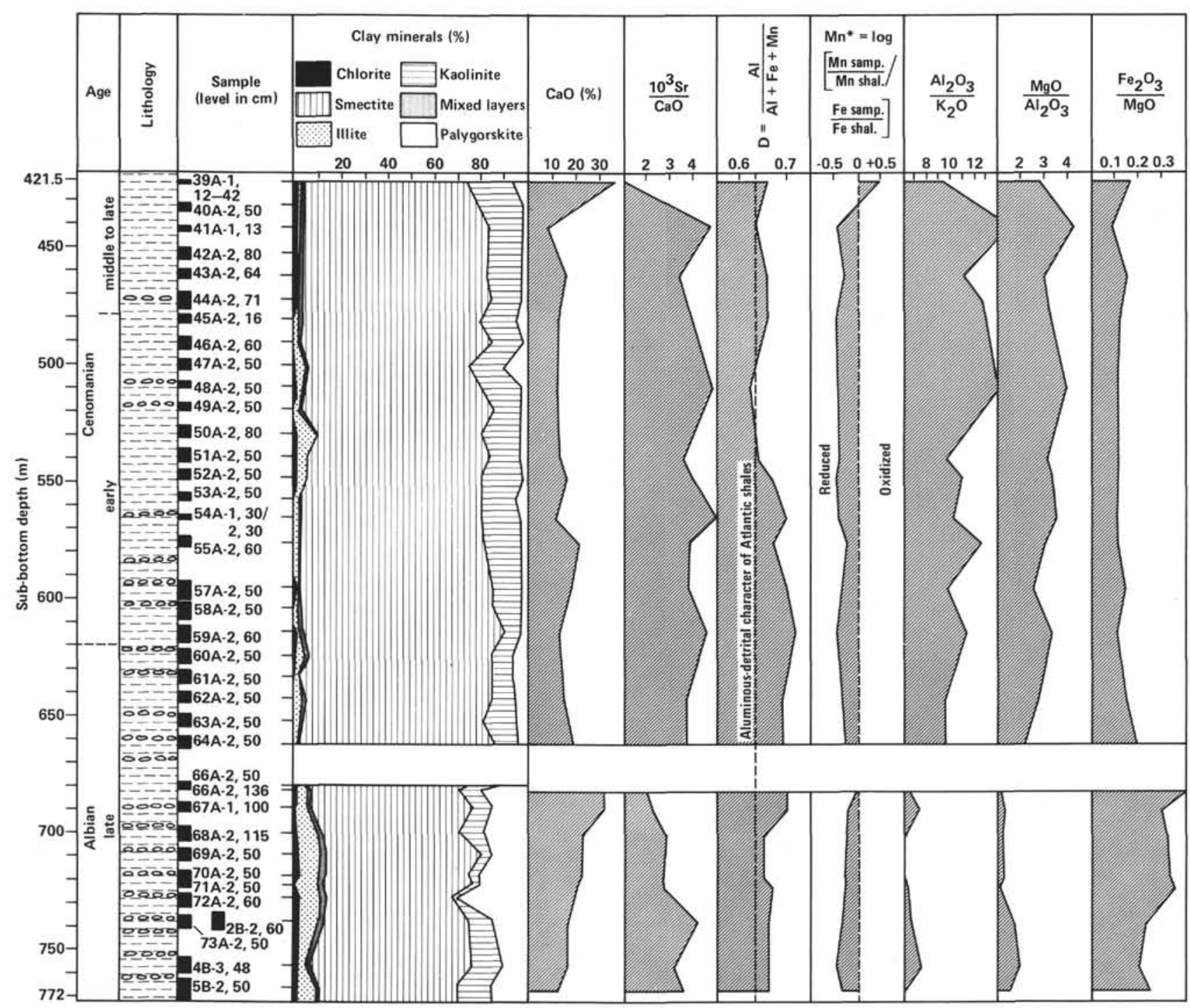

Figure 4. Cretaceous clay mineralogy and bulk geochemistry, Site 547.

cally active Atlas Mountains. Moreover, some mineralogical and geochemical differences do exist between Site 546 and Hole 547, and vertically oriented changes occur above the salt at Site 546 and not in Hole 547B. These data cannot be easily explained in an epimetamophic context (see later). Thus, we do prefer the hypothesis of a strong mechanical erosion of sloped continental relieves.

In spite of a comparable background of inorganic components, the lower Mesozoic reddish sediments of Site 546 and Hole 547B show significant differences, which are summarized in Table 4.

Site 546 sediments appear to be strongly influenced by the evaporitic environment. Chlorite is 25 to $30 \%$ more abundant than in the Hole 547B deposits, and its morphology seen by transmission electromicroscopy is exceptionally well shaped and often occurs as automorphous polygons (Plate 3, Figs. 4-6). Chlorite abundance roughly decreases above the halite deposits of Site 546. Regular mixed-layer clays occur as allevardite (illite-smectite) and later on as corrensite (chlorite-smectite), two minerals that are often associated with saline, restricted environments (Lucas, 1962). These minerals are characterized by automorphous forms, partly as laths for allevardite (?) (Plate 3, Figs. 1-3), and as wellshaped polygons for corrensite (Plate 2, Figs. 5, 6). The geochemistry at Site 546 points to the existence of a sodic character with a hypersaline environment passing into a common hemipelagic one: hypersodic (Core 546-20 to sample $546-18-2,144 \mathrm{~cm}$ ), sulphatic immediately above the salt $(544-18-1,110 \mathrm{~cm}$ to $546-17-4,45 \mathrm{~cm})$, magnesian $(546-17-2,130 \mathrm{~cm}$ to $546-17-2,36 \mathrm{~cm})$ and calcitic (546-17-1-50, 546-17-1, $18 \mathrm{~cm})$. Such changes do not occur at Site 547 , which is marked by a potassic character linked to the illite abundance, and which does not show the presence of saline evaporites above the continental crust. Microprobe investigations on $<1 \mu \mathrm{m}$ particles of chlorite show a magnesian character at the base of both sites, with an increase of Fe content upward. However, the chlorite is more strongly enriched in $\mathrm{Mg}$ at Site 546 (Core 546-18) than at Site 547. To conclude, the reddish sediments of Hole 547B are probably the result of the fast erosion of emerged sialic rocks with 
Table 2. Mineralogical and geochemical correlations between Site 547 and Site 545 black shales.

\begin{tabular}{|c|c|c|c|c|}
\hline \multicolumn{2}{|c|}{ Site $547^{a}$} & \multicolumn{2}{|c|}{ Site 545} & \\
\hline Cores & Data & Data & Cores & \\
\hline $\begin{array}{l}51 A-52 A \\
54 A-55 A \\
57 A-64 A \\
66 A-73 A \\
+(5 B-2 B) \\
\end{array}$ & $\begin{array}{l}0 \\
0.37 \\
0 \\
0.06 \\
(0.16) \\
\end{array}$ & $\begin{array}{l}- \\
0.20 \\
0 \\
0.18\end{array}$ & $\begin{array}{c}29-31 \\
33 \\
34-37 \\
38-40\end{array}$ & $\mathrm{P}_{2} \mathrm{O}_{5}(\%)$ \\
\hline $\begin{array}{l}51 \mathrm{~A}-64 \mathrm{~A} \\
66 \mathrm{~A}-73 \mathrm{~A} \\
2 \mathrm{~B}-5 \mathrm{~B} \\
\end{array}$ & $\begin{array}{r}11.32 \\
6.55 \\
\end{array}$ & $\begin{array}{r}10.01 \\
6.59 \\
\end{array}$ & $\begin{array}{l}29-37 \\
38-40\end{array}$ & $\frac{\mathrm{Al}_{2} \mathrm{O}_{3}}{\mathrm{~K}_{2} \mathrm{O}} \circlearrowleft$ \\
\hline $\begin{array}{l}51 A-64 A \\
66 A-73 A \\
2 B-5 B\end{array}$ & $\begin{array}{l}3.20 \\
1.23\end{array}$ & $\begin{array}{l}2.97 \\
1.47\end{array}$ & $\begin{array}{l}29-37 \\
38-40\end{array}$ & $\frac{\mathrm{Fe}_{2} \mathrm{O}_{3}}{\mathrm{MgO}}$ \\
\hline $\begin{array}{l}60 A-64 A \\
66 A-73 A \\
2 B-5 B \\
\end{array}$ & & & $\begin{array}{c}37 \\
37-40\end{array}$ & Illite \\
\hline $\begin{array}{l}39 \mathrm{~A} \\
60 \mathrm{~A}-64 \mathrm{~A} \\
66 \mathrm{~A}-73 \mathrm{~A} \\
2 \mathrm{~B}-5 \mathrm{~B} \\
\end{array}$ & & & $\begin{array}{c}29-31 \\
37 \\
37-40\end{array}$ & Smectite 늘 \\
\hline $\begin{array}{l}40 A-59 A \\
60 A-64 A \\
66 A-73 A \\
2 B-5 B \\
\end{array}$ & & & $\begin{array}{c}32-36 \\
37 \\
37-40\end{array}$ & Kaolinite 芩 \\
\hline $\begin{array}{l}39 A \\
40 A-59 A \\
60 A-64 A \\
66 A-73 A \\
2 B-5 B\end{array}$ & & & $\begin{array}{c}29-31 \\
32-36 \\
37 \\
37-40\end{array}$ & Palygorskite \\
\hline
\end{tabular}

little subaerial weathering. On the other hand, Site 546 reddish sediments point to the existence of additional diagenetic processes marked by mineral growths in a restricted evaporite environment.

\section{CONCLUSIONS}

Mineralogical and geochemical analyses were performed on 115 samples from selected time slices of Leg 79 drill sites.

The Upper Cretaceous to lowest Tertiary claystones to marlstones recovered in Hole 547A are rich in smectite and also contain fibrous clays. These sediments mineralogically resemble the lower Paleocene deposits of the northeast Atlantic.

The upper Albian and Cenomanian redeposited green nannofossil claystones of Site 545 and Hole 547A contain similar clay and geochemical assemblages: high smectite contents, very low metalliferous accumulation, reduced environments, strong terrigenous influence, and high sedimentation rates. These assemblages suggest the existence of a hot climate with humidity-contrasted seasons along northwest Africa. Moderate but significant variations occur in the relative abundance of illite, smectite, kaolinite, palygorskite, $\mathrm{P}_{2} \mathrm{O}_{5}, \mathrm{Al}_{2} \mathrm{O}_{3}, \mathrm{~K}_{2} \mathrm{O}, \mathrm{Fe}_{2} \mathrm{O}_{3}$, and $\mathrm{MgO}$. The variations recorded are parallel in both DSDP sites. The trends observed in the inorganic stra- tigraphy support the biostratigraphical zonation in these series, which is marked by dissolution and resedimentation processes. Systematic lower content of smectite and higher contents of illite and kaolinite at Site $545 \mathrm{com}$ pared to Site 547 suggest the occurrence of differential settling processes, the former site being more proximal and the latter one more distal.

The upper Aptian to middle Albian green nannofossil claystones recovered at Site 545 are characterized by strong variations in the clay mineralogy and the inorganic geochemistry, especially as far as illite, smectite, palygorskite, $\mathrm{MgO}, \mathrm{K}_{2} \mathrm{O}$, and $\mathrm{P}_{2} \mathrm{O}_{5}$ are concerned. These variations, recorded in an environment marked by reduced conditions, high sedimentation rates, and strong terrigenous influences, suggest an alternation of tectonically active and relaxed periods on the African margin, possibly in relation with the irregular spreading activity of the Mid-Atlantic Ridge.

The lower Mesozoic reddish claystones to mudstones of Site 546 and Hole 547B contain chiefly chlorite and smectite, associated with $\mathrm{Li}$, and indicate strong physical erosion of high-relief sialic rocks. There is evidence of marked pedologic or post-depositional metamorphic processes. Unpublished studies show that the same results concern the barren grayish red sandy mudstones of Site 544. Site 546 halite and associated sediments, as well as the overlying pre-Miocene deposits, show higher chlorite contents, the local presence of regular mixed-layer clays (corrensite, allevardite), higher $\mathrm{Na}_{2} \mathrm{O} / \mathrm{K}_{2} \mathrm{O}$ ratios, and upward geochemical sequences marked by successive dominances of $\mathrm{Na}, \mathrm{SO}_{4}, \mathrm{Mg}$, and $\mathrm{Ca}$ parallel to a chlorite decrease. All these peculiarities point to the existence, at Site 546 only, of various early diagenetic processes in an alkaline, confined environment, from hypersaline conditions to hemipelagic ones.

\section{ACKNOWLEDGMENTS}

We are grateful to the U.S. National Science Foundation and to the Leg 79 Shipboard Party for giving us the opportunity to study sedimentary materials of Mazagan Plateau. The financial support of the study was given by CNRS (France) through Grant ATP GGO 1982. Technical and scientific assistance from M. Bocquet, J. Carpentier, F. Dujardin, E. Hanton, M. Leckie, A. Piqué, and P. Récourt are gratefully acknowledged.

\section{REFERENCES}

CEPM Laboratory, 1980. Results of X-ray mineralogy analyses of samples from Deep Sea Drilling Project Sites 415 and 416, Moroccan Basin. In Lancelot, Y., Winterer, E. L., et al., Init. Repts. DSDP, 50: Washington (U.S. Govt. Printing Office), 707-713.

Chamley, H., 1979. North Atlantic clay sedimentation and paleoenvironment since the late Jurassic. In Talwani, M., Hay, W., Ryan, W. B. F. (Eds.), Deep Drilling Research Altantic Ocean: Continental Margins and Paleoenvironment. Am. Geophys. Union, Maurice Ewing Ser., 3:342 -361.

Chamley, H., Giroud D'Argoud, G., and Robert, C., 1980. Clay mineralogy of Cretaceous and Cenozoic sediments off the Moroccan margin, Deep Sea Drilling Project Sites 415 and 416. In Lancelot, Y., Winterer E. L., et al., Init. Repts. DSDP, 50: Washington (U.S. Govt. Printing Office), 715-724.

Debrabant, P., and Foulon, J., 1979. Expression géochimique des variations du paléoenvironment depuis le Jurassique supérieur sur les marges nord-atlantiques. Oceanol. Acta, 2:469-476.

Gibbs, R. J., 1977. Clay mineral segregation in the marine environment. J. Sed. Petrol. 47:237-243. 
Lucas, J., 1962. La Transformation des Minéraux Argileux dans la Sédimentation. Etudes Sur Les Argiles du Trias. Mem. Serv. Geol. Als.-Lorr., 23.

Maillot, H., and Robert, C., 1980. Minéralogie et géochimie des sédiments crétacés et cénozoiques dans l'Océan Atlantique sud (marge africaine, dorsale médio-atlantique). Bull. Soc. Geol. France, 22: (7):777-788.

Mélières, F., 1978. X-ray mineralogy studies, DSDP Leg 41. In Lancelot, Y., Seibold, E., et al., Init. Repts. DSDP, 41: Washington (U.S. Govt. Printing Office), 1065-1086.
Millot, G., 1964. Géologie des Argiles: Paris (Masson).

Robillard, D., and Piqué, A., 1981. Epitétamorphisme du Permo-Trias dans le Moyen-Atlas septentrional (Maroc): mise en évidence et zonation régionale. Rev. Geol. Dyn. Geogr. Phys., 23:301-308.

Whitehouse, V. G., Jeffrey, L. M., and Debrecht, J. D., 1960. Differential settling tendances of clay minerals in saline waters. Clays Clay Min. (7th Nat. Conf.), 1958:1-80.

Date of Initial Receipt: March 1, 1983

Date of Acceptance: September 6, 1983

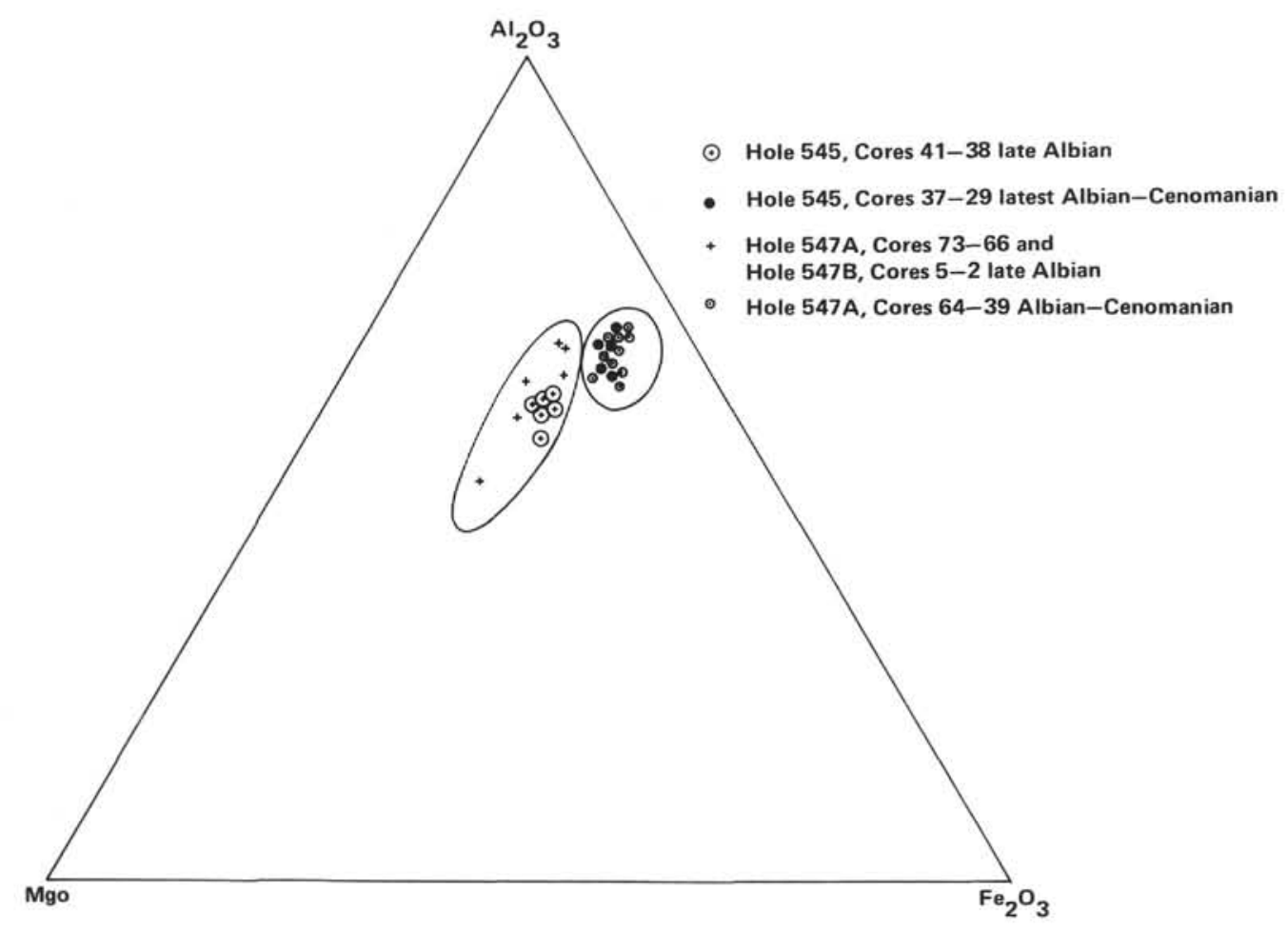

Figure 5. Geochemical identification of late Albian and latest Albian-Cenomanian time intervals, Sites 545 and 547. 


\section{H. CHAMLEY, P. DEBRABANT}

Table 3. Geochemical analysis.

\begin{tabular}{|c|c|c|c|c|c|c|c|c|c|c|c|c|c|c|c|c|c|c|c|}
\hline \multirow{2}{*}{$\begin{array}{c}\text { Sample } \\
\text { (interval in } \mathrm{cm} \text { ) }\end{array}$} & \multicolumn{9}{|c|}{ Major element oxides (\%) } & \multicolumn{10}{|c|}{ Trace elements (ppm) } \\
\hline & $\mathrm{SiO}_{2}$ & $\mathrm{Al}_{2} \mathrm{O}_{3}$ & $\mathrm{Fe}_{2} \mathrm{O}_{3}$ & $\mathrm{CaO}$ & $\mathrm{MgO}$ & $\mathrm{Na}_{2} \mathrm{O}$ & $\mathrm{K}_{2} \mathrm{O}$ & $\mathrm{TiO}_{2}$ & $\mathrm{P}_{2} \mathrm{O}_{5}$ & Sr & Mn & $\mathrm{Zn}$ & $\mathrm{Li}$ & $\mathrm{Ni}$ & $\mathrm{Cr}$ & Co & $\mathrm{Cu}$ & $\mathrm{Pb}$ & $\mathrm{v}$ \\
\hline \multicolumn{20}{|l|}{ Site 545} \\
\hline $29-2,24-26$ & 34.90 & 13.43 & 5.27 & 18.00 & 1.58 & 1.06 & 1.05 & 0.40 & n.d. & 615 & 342 & 116 & 36 & 38 & 95 & 15 & 10 & 17 & 140 \\
\hline $31-1,77-79$ & 31.90 & 12.29 & 5.39 & 19.78 & 2.28 & 0.87 & 1.43 & 0.32 & n.d. & 489 & 473 & 110 & 36 & 53 & 104 & 18 & 10 & 28 & 100 \\
\hline $33-1,40-43$ & 35.20 & 13.59 & 5.18 & 17.48 & 1.92 & 0.94 & 1.53 & 0.33 & 0.20 & 531 & 258 & 142 & 40 & 59 & 100 & 15 & 13 & 24 & 120 \\
\hline $34-2,70-71$ & 40.00 & 16.45 & 6.28 & 11.50 & 1.69 & 1.18 & 1.70 & 0.39 & n.d. & 458 & 216 & 168 & 54 & so & 124 & 17 & 16 & 30 & 150 \\
\hline $37-2,40-42$ & 39.30 & 14.76 & 6.68 & 12.62 & 2.43 & 1.18 & 1.46 & 0.40 & n.d. & 421 & 226 & 242 & 44 & 55 & 102 & 16 & 16 & 25 & 130 \\
\hline $38-2,100-101$ & 12.20 & 3.86 & 1.63 & 36.86 & 2.36 & 0.52 & 0.70 & 0.10 & 0.41 & 899 & 137 & 163 & to & 56 & 62 & 12 & 19 & 36 & 70 \\
\hline $38-3,101-102$ & 22.10 & 8.38 & 3.12 & 28.68 & 1.99 & 0.69 & 1.14 & 0.20 & n.d. & 657 & 174 & 163 & 25 & 44 & 77 & 12 & 18 & 26 & 90 \\
\hline $39-2,59-61$ & 39.30 & 14.57 & 4.66 & 13.34 & 2.83 & 0.95 & 1.96 & 0.27 & n.d. & 421 & 231 & 184 & 49 & 39 & 95 & 9 & 15 & 24 & 130 \\
\hline $40-1,64-66$ & 19.20 & 5.69 & 2.07 & 31.06 & 2.19 & 0.61 & 0.98 & 0.13 & 0.27 & 889 & 116 & 300 & 16 & 49 & 68 & 5 & 29 & 27 & 80 \\
\hline $40-5,58-60$ & 29.30 & 9.39 & 3.05 & 22.84 & 3.01 & 0.82 & 1.37 & 0.17 & 0.24 & 526 & 163 & 379 & 24 & 41 & 63 & II & 99 & 26 & 170 \\
\hline $41-3,78-80$ & 36.40 & 8.97 & 2.67 & 19.32 & 1.79 & 0.79 & 1.96 & 0.24 & 0.35 & 394 & 121 & 542 & 23 & 80 & III & 5 & 41 & 18 & 120 \\
\hline $44-2,14-18$ & 32.90 & 8.69 & 2.90 & 22.61 & 1,97 & 0.77 & 1.90 & 0.18 & n.d. & 437 & 137 & 431 & 19 & 31 & 82 & 5 & 35 & 30 & 70 \\
\hline $46-1,75-77$ & 28.10 & 8.02 & 2.67 & 25.93 & 1.85 & 0.65 & 1.72 & 0.18 & n.d. & 442 & 95 & 268 & 16 & 38 & 63 & 9 & 23 & 27 & 70 \\
\hline $48-5,75-77$ & 36.50 & 9.70 & 3.17 & 19.92 & 2,40 & 0.82 & 2.05 & 0.21 & n.d. & 373 & 121 & 252 & 21 & 35 & 78 & 7 & 35 & 22 & 80 \\
\hline $49.4,8-10$ & 25.90 & 5.41 & 1.75 & 29.60 & 1.61 & 0.56 & 1.30 & 0.13 & n.d. & 389 & 110 & 552 & 11 & 32 & 56 & 4 & 34 & 30 & 50 \\
\hline $50-4,57-59$ & 21.30 & 4.72 & 1.94 & 32.54 & 1.51 & 0.55 & 1.17 & 0.13 & n.d. & 431 & 147 & 368 & 10 & 29 & 59 & 6 & 48 & 29 & 40 \\
\hline $51-6,28-30$ & 22.70 & 5.39 & 2.11 & 30.97 & 1.50 & 0.59 & 1.33 & 0.16 & n.d. & 400 & 116 & 242 & 10 & 28 & 58 & 11 & 47 & 31 & 40 \\
\hline $55, \mathrm{CC}, 17-19$ & 30.30 & 7.41 & 2.68 & 22.51 & 3.27 & 0.56 & 1.65 & 0.19 & n.d. & 237 & 126 & 663 & is & 35 & 60 & 9 & 25 & 28 & 70 \\
\hline $56-6,59-61$ & 28.40 & 8.04 & 3.10 & 15.38 & 11.10 & 0.68 & 1.99 & 0.20 & 0.20 & 89 & 142 & 416 & 19 & 24 & 59 & n.d. & 27 & 24 & 60 \\
\hline \multicolumn{20}{|l|}{ Hole $547 \mathrm{~A}$} \\
\hline $39.1,42$ & 13.00 & 6.22 & 2.97 & 36.57 & 1.03 & 0.46 & 0.66 & 0.27 & n.d. & 358 & 826 & 89 & 19 & 54 & 58 & 15 & 14 & 36 & 50 \\
\hline $41-1,13$ & 44.00 & 18.32 & 7.26 & 7.40 & 1.69 & 1.33 & 1.21 & 0.5 & n.d. & 352 & 252 & 126 & 62 & 56 & $2 \mathrm{t}$ & is & 12 & 15 & 140 \\
\hline $43.2,64$ & 35.70 & 13.95 & 6.45 & 15.24 & 2.12 & 1.07 & 1.24 & 0.19 & n.d. & 515 & 332 & 126 & 47 & 52 & 100 & 13 & 20 & 28 & 70 \\
\hline $45-2,18$ & 38,80 & 15.36 & 6.07 & 12.67 & 1.81 & 1.31 & 1.21 & 0.27 & n.d. & 494 & 206 & 147 & 48 & 59 & 123 & 11 & 17 & 22 & 120 \\
\hline $48-2,50$ & 39.50 & 15.65 & 6.78 & 11.35 & 1.70 & 1.36 & 1.10 & 0.45 & n.d. & 547 & 227 & 121 & 50 & 55 & 118 & 8 & 14 & 28 & 140 \\
\hline $51-2,50$ & 37.80 & 15.90 & 6.25 & 12.81 & 1.96 & 1.35 & 1.61 & 0.38 & n.d. & 452 & 242 & 163 & 47 & 70 & 139 & 12 & 16 & 20 & 120 \\
\hline $52-2,50$ & 33.30 & 14.85 & 5.90 & 15.70 & 1.75 & 1.17 & 1.34 & 0.21 & n.d. & 621 & 205 & 105 & 49 & 58 & 115 & 11 & 29 & 52 & 100 \\
\hline $54-1,30$ & 39.10 & 17.16 & 6.71 & 10.32 & 1.87 & 1.29 & 1.66 & 0.31 & 0.46 & 515 & 242 & 116 & 57 & 51 & 124 & 15 & 17 & 19 & 140 \\
\hline $55-2,60$ & 31.20 & 12.82 & 4.98 & 21.11 & 1.60 & 1.08 & 1.01 & 0.32 & 0.27 & 815 & 279 & 121 & 38 & 44 & 97 & 10 & 23 & 31 & 110 \\
\hline $57-2,50$ & 36.00 & 13.65 & 5.34 & 17.71 & 2.06 & 1.13 & 1.39 & 0.32 & n.d. & 672 & 226 & 105 & 39 & 45 & 107 & 9 & 19 & 30 & 110 \\
\hline $59-2,50$ & 41.00 & 15.39 & 6.18 & 12.77 & 1.84 & 1.47 & 1.34 & 0.28 & n.d. & 579 & 210 & 126 & 41 & 45 & 97 & 13 & 20 & 29 & 130 \\
\hline $62-2,50$ & 37.10 & 14.52 & 6.12 & 14.11 & 2.25 & 1.34 & 1.50 & 0.40 & n.d. & 515 & 258 & 116 & 40 & 60 & 118 & 17 & 17 & 23 & 140 \\
\hline $64-2,50$ & 33.50 & 12.38 & 5.19 & 18.34 & 2.45 & 1.08 & 1.30 & 0.36 & n.d. & 673 & 268 & 216 & 36 & 47 & 111 & 12 & 27 & 35 & 130 \\
\hline $66-2,136$ & 15.80 & 5.99 & 2.73 & 31.54 & 2.42 & 0.58 & 0.91 & 0.16 & n.d. & 631 & 226 & 163 & 17 & 55 & 81 & 13 & 18 & so & 70 \\
\hline $67-1,100$ & 18.10 & 6.75 & 2.65 & 31.18 & 2.03 & 0.72 & 0.92 & 0.19 & n.d. & 694 & 153 & 89 & 19 & 50 & 82 & 11 & 32 & 30 & 80 \\
\hline $68-2,115$ & 27.20 & 9.66 & 3.70 & 22.78 & 3.10 & 0.82 & 1.57 & 0.20 & n.d. & 642 & 189 & 116 & 28 & 57 & 117 & 15 & 22 & 33 & 100 \\
\hline $70-2,50$ & 29.00 & 10.41 & 4.21 & 21.43 & 3.42 & 0.85 & 1.74 & 0.21 & n.d. & 573 & 200 & 174 & 32 & 49 & 114 & 13 & 31 & 30 & 120 \\
\hline $71-2,50$ & 32.40 & 10.22 & 3.82 & 19.45 & 3.56 & 0.92 & 1.62 & 0.22 & n.d. & 531 & 195 & 116 & 27 & 40 & 90 & 11 & 25 & 27 & 100 \\
\hline 73.2 .50 & 38.50 & 13.68 & 5.20 & 12.51 & 3.31 & 1.13 & 2.17 & 0.24 & n.d. & 579 & 216 & 110 & 40 & 48 & 117 & 12 & 20 & 43 & 130 \\
\hline Site 546 & & & & & & & & & & & & & & & & & & & \\
\hline h. & 8.60 & 3.53 & 1.79 & 40.7 & 1.1 & 1.5 & 0.94 & 0.1 & n.c & 205 & 1362 & 74 & 12 & 30 & 34 & 18 & 18 & 40 & 30 \\
\hline 17.1 , & 13.70 & 4.81 & 2.40 & 36.45 & 1.48 & 2.03 & 1.34 & 0.21 & n.d. & 189 & 1036 & 79 & 14 & 31 & 32 & 17 & 21 & 40 & 40 \\
\hline $17-2,3$ & 20.40 & 6.44 & 21.57 & 8.90 & 7.18 & 1.54 & 1.61 & 0.29 & n.d. & 431 & 7222 & 53 & 39 & 43 & 52 & 37 & 74 & 58 & so \\
\hline & 20 & 11.19 & 6.81 & & 7. & 2. & 2.11 & 0. & & 126 & 584 & 105 & 127 & 34 & 74 & 16 & 9 & 37 & 80 \\
\hline $17-2,130$ & 44.60 & 14.64 & 7.13 & 3.86 & 7.12 & 3.24 & 3.01 & 0. & n. & 179 & 384 & 95 & 149 & 44 & 97 & 19 & 10 & 20 & 110 \\
\hline $17-3,4$ & 20.90 & 8.17 & 4.21 & 25.88 & 1.38 & 3.04 & 2.13 & 0.3 & n.c & 331 & 410 & 226 & 28 & 47 & 65 & 20 & 25 & 44 & 80 \\
\hline $17-$ & 44.40 & 14.29 & 4.71 & 2.60 & 8.2 & 4. & 3.65 & 0. & n. & 100 & 337 & 132 & 157 & 42 & 111 & 14 & 1 & 79 & 100 \\
\hline $17-4$, & 11.70 & 4.62 & 1.75 & 27.95 & 2.48 & 0.9 & 0.85 & 0.1 & $\mathrm{n}$. & 205 & 142 & 105 & 51 & 12 & 33 & n.d. & 6 & 69 & 40 \\
\hline $18-1,75$ & 28.90 & 9.97 & 3.93 & 14.05 & 6.20 & 2.4 & 2.16 & 0.3 & $\mathrm{n} . \mathrm{c}$ & 159 & 247 & 137 & 121 & 27 & 52 & 3 & 21 & 46 & 80 \\
\hline $18-1,110$ & 19.20 & 7.63 & 2.66 & 21.66 & 4.59 & 2.20 & 1.66 & 0.28 & n.d. & 210 & 205 & 195 & 86 & 23 & 47 & 5 & 13 & 54 & 60 \\
\hline Hole 548B & & & & & & & & & & & & & & & & & & & \\
\hline $2-2,50$ & 3. & 12. & 4. & 17. & 2. & 1. & 1. & 0. & 0. & 6 & 221 & 1 & 37 & 58 & 113 & 10 & 21 & 23 & 110 \\
\hline & 39 & 13 & & is. 37 & 2. & i. & i. & 0.2 & 0. & 479 & 168 & 137 & 46 & 56 & 125 & 10 & 30 & 24 & 120 \\
\hline $5-2$ & 42 & 14 & 5. & 11.19 & 3. & 1. & 2. & 0.2 & 0. & 400 & 231 & 137 & 48 & 69 & 143 & 12 & 22 & 24 & 130 \\
\hline $25-3$ & 46.50 & 14.87 & 6.85 & 6.24 & 7.10 & 0.56 & 4.62 & 0.36 & n. & 89 & 610 & 74 & 117 & 65 & 87 & 15 & n.d. & 51 & 90 \\
\hline $25-4,91$ & 47.60 & 17.31 & 4.92 & $6 . C$ & 4.89 & 0.60 & 4.58 & 0.40 & n. & 95 & 410 & 137 & 124 & 60 & 105 & 20 & n.d. & 35 & 110 \\
\hline $26-2$, ic & & 16 & 6. & 5. & 5. & 0. & 4. & 0. & n. & 110 & 416 & 100 & 122 & 50 & 90 & 13 & n.d. & 74 & 100 \\
\hline $26-4,60$ & 44.40 & 14.58 & 4.31 & 6.87 & 7.55 & 0.60 & 3.69 & 0.33 & $\mathrm{n}$. & 126 & 931 & 79 & 131 & 88 & 103 & 47 & $?$ & 310 & 100 \\
\hline 27. & & 18. & 7. & 3. & s. & 0. & 4. & 0. & & 110 & 358 & 95 & 130 & 68 & 97 & 18 & n.d. & 26 & 120 \\
\hline 27. & & 14 & 4. & 8. & $s$. & 0. & 3. & 0. & & 74 & 500 & 68 & 122 & 83 & 128 & 14 & 21 & 90 & 90 \\
\hline $28-4,80$ & 47.50 & 15.49 & 6.34 & 5.97 & 6.12 & 0.47 & 3.73 & 0.38 & n.c & 126 & 521 & 95 & 121 & 67 & 101 & 18 & n.d. & 37 & 100 \\
\hline 29 - & & 15 & 5. & 10.98 & 5. & 0. & 3. & 0. & 0. & 163 & 494 & 89 & 110 & so & 86 & 13 & 104 & 48 & 100 \\
\hline & & 15.27 & 4. & 11.0 & 5 & 0. & 3. & 0. & 0. & 174 & 579 & 89 & 140 & 72 & 102 & 16 & 74 & 19 & 90 \\
\hline $31-3,90$ & 44.00 & 14.77 & 5.66 & 9.35 & 4.71 & 0.54 & 3.74 & 0.33 & n.c & 168 & 726 & 110 & 121 & so & 82 & 12 & n.d. & 15 & 100 \\
\hline $33, \mathrm{CC}, 21$ & 48.50 & 16.01 & 6.6 & 6.59 & 4.16 & 0.51 & 4.38 & 0.37 & n.c & 137 & 663 & 100 & 122 & 55 & 84 & 17 & n.d. & 35 & 100 \\
\hline $34-2,100$ & 50.50 & 17.65 & 7.39 & 5.37 & 3.30 & 0.58 & 4.70 & 0.36 & n.d. & 137 & 794 & 216 & 115 & 58 & 76 & 16 & n.d. & 23 & 100 \\
\hline
\end{tabular}

Note: $\mathrm{n} . \mathrm{d} . \mathrm{m}$ no data.

Table 4. Main mineralogical and geochemical differences between Holes 546 and 547B reddish sediments.

\begin{tabular}{|c|c|c|}
\hline & $\begin{array}{l}\text { Hole 546, } \\
\text { Cores 17-21 }\end{array}$ & $\begin{array}{l}\text { Hole } 547 \mathrm{~B} \text {, } \\
\text { Cores } 25-34\end{array}$ \\
\hline Chlorite/illite & $2.3>\mathrm{C} / \mathrm{I}>0.5$ & $0.5>\mathrm{C} / \mathrm{I}>0.3$ \\
\hline $\begin{array}{l}\text { Regular mixed- } \\
\text { layer clays }\end{array}$ & $\begin{array}{l}\text { Corrensite }(17=3,89 \mathrm{~cm}) \\
\text { Allevardite }(18=3,18 \mathrm{~cm})\end{array}$ & Absent \\
\hline Halite & Abundant & Absent \\
\hline Anhydrite & Present & Absent \\
\hline $\begin{array}{l}\mathrm{Na}_{2} \mathrm{O} / \mathrm{K}_{2} \mathrm{O} \\
\quad \text { (see also Fig. 7) }\end{array}$ & $1.43>\mathrm{Na} / \mathrm{K}>1.08$ & $0.14 \pm 0.02$ \\
\hline $\begin{array}{l}\text { Vertical evolution } \\
\text { upward }\end{array}$ & $\begin{array}{l}\text { Strong: } \mathrm{Na}-, \mathrm{SO}_{4-}, \mathrm{Mg}-\text { and } \\
\text { Ca-rich successive dominances } \\
\text { Irregular and strong de- } \\
\text { crease of chlorite above } \\
\text { the halite-rich deposits, } \\
\text { parallel to the main geo- } \\
\text { chemical changes }\end{array}$ & $\begin{array}{l}\text { Weak: slight increase of } \\
\text { chlorite }\end{array}$ \\
\hline
\end{tabular}



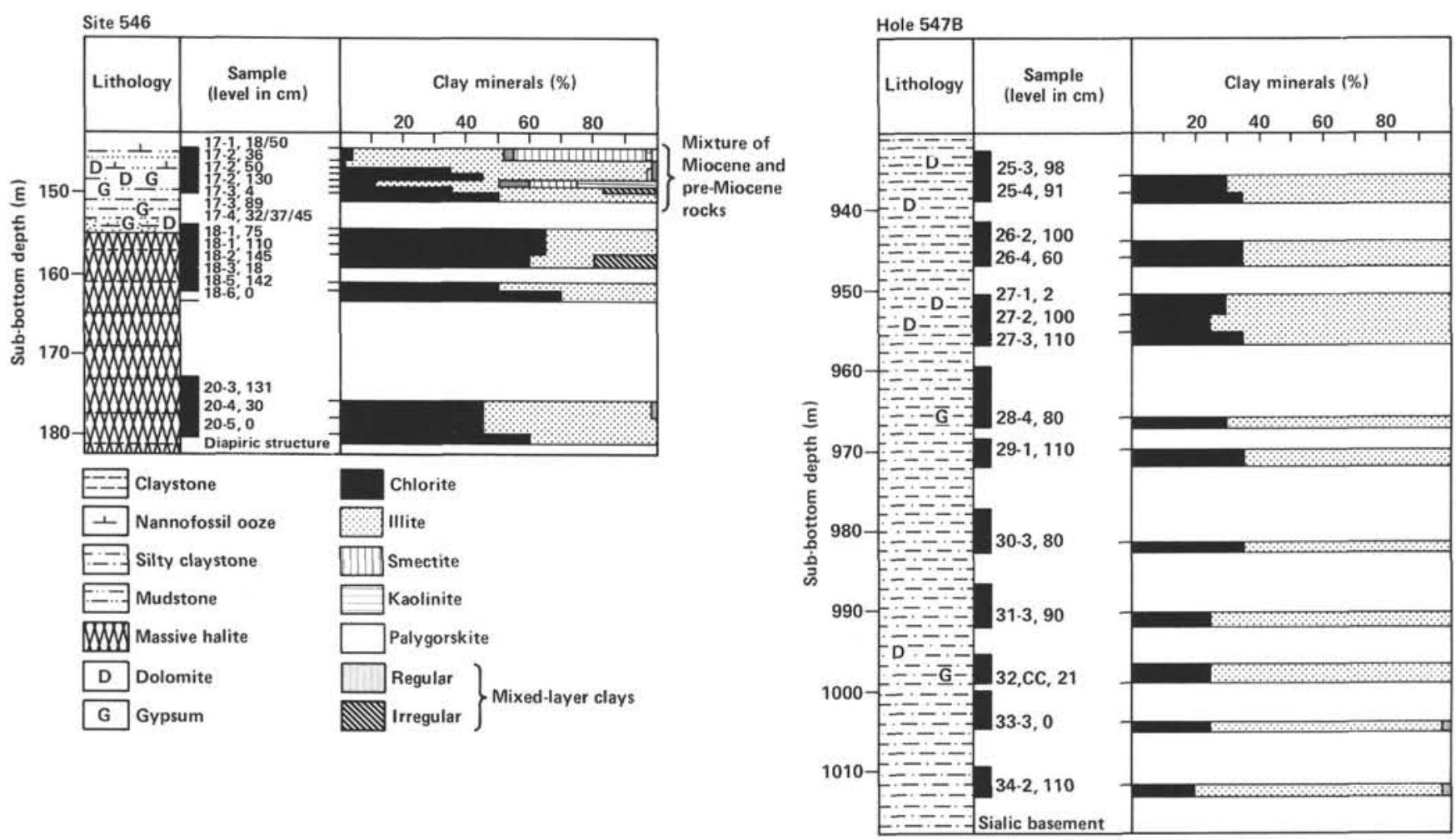

Figure 6. Early Mesozoic clay mineralogy, Sites 546 and 547.

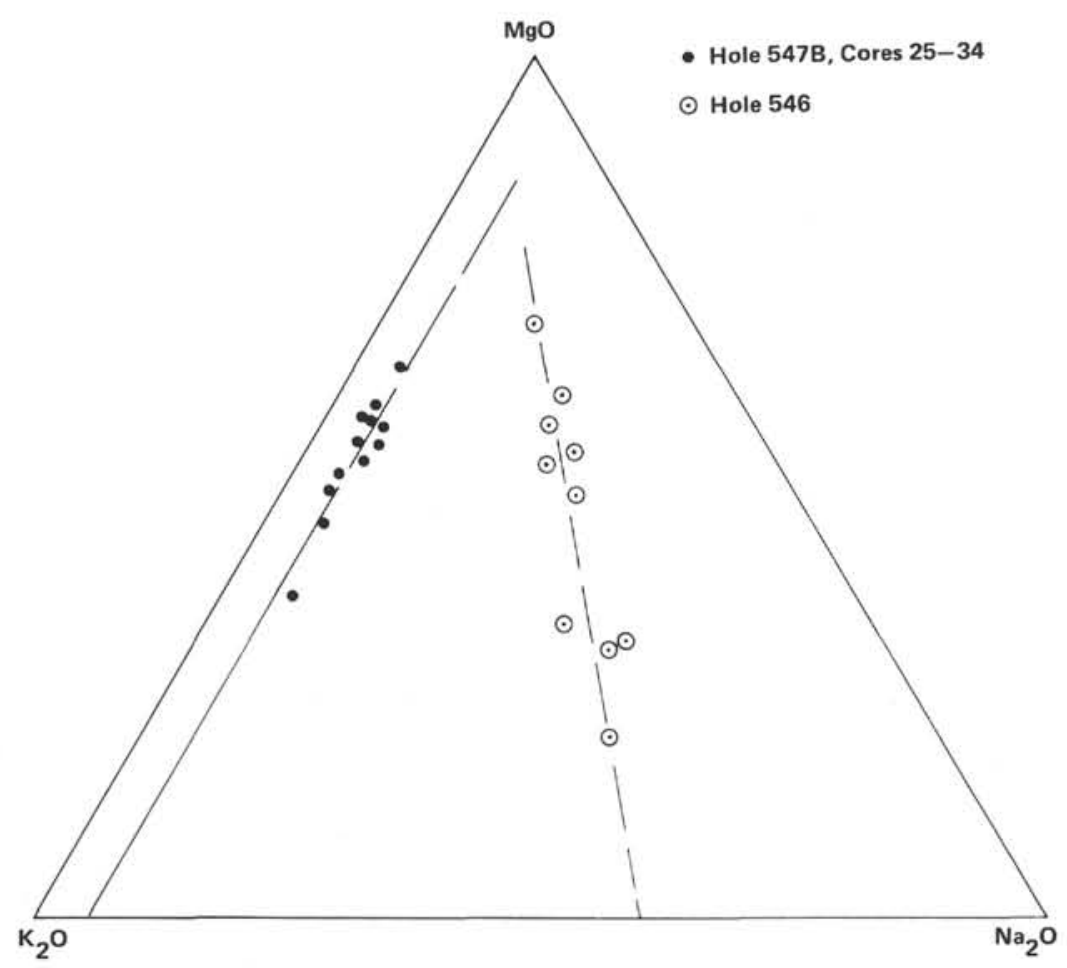

Figure 7. Geochemical data, Sites 546 and 547. 

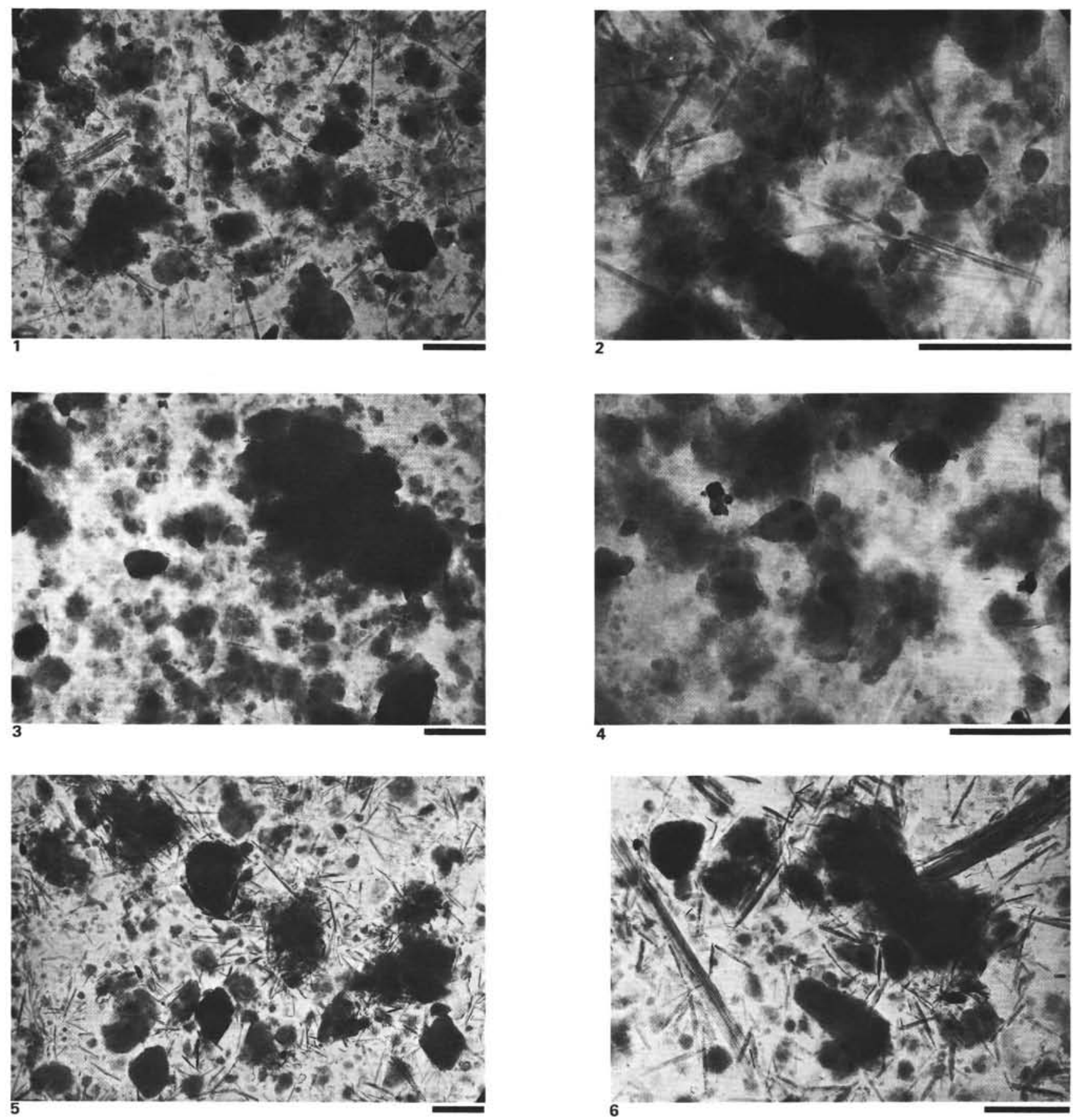

Plate 1. Electromicrographs. (Scale bar $=1 \mu \mathrm{m}$.) 1, 2. Cenomanian, Sample 547A-39-1, $12 \mathrm{~cm}$. Abundant smectite, common palygorskite broken fibers, some kaolinite hexagons. 3,4. Cenomanian, Sample $547 \mathrm{~A}-49-2,50 \mathrm{~cm}$. Very abundant smectite with blurred contours, rare kaolinite, and palygorskite. 5,6. Aptian, Sample $545-48-5,78 \mathrm{~cm}$. Comparable amounts of illite, smectite and palygorskite. Many palygorskite fibers are still in compact bundles. 

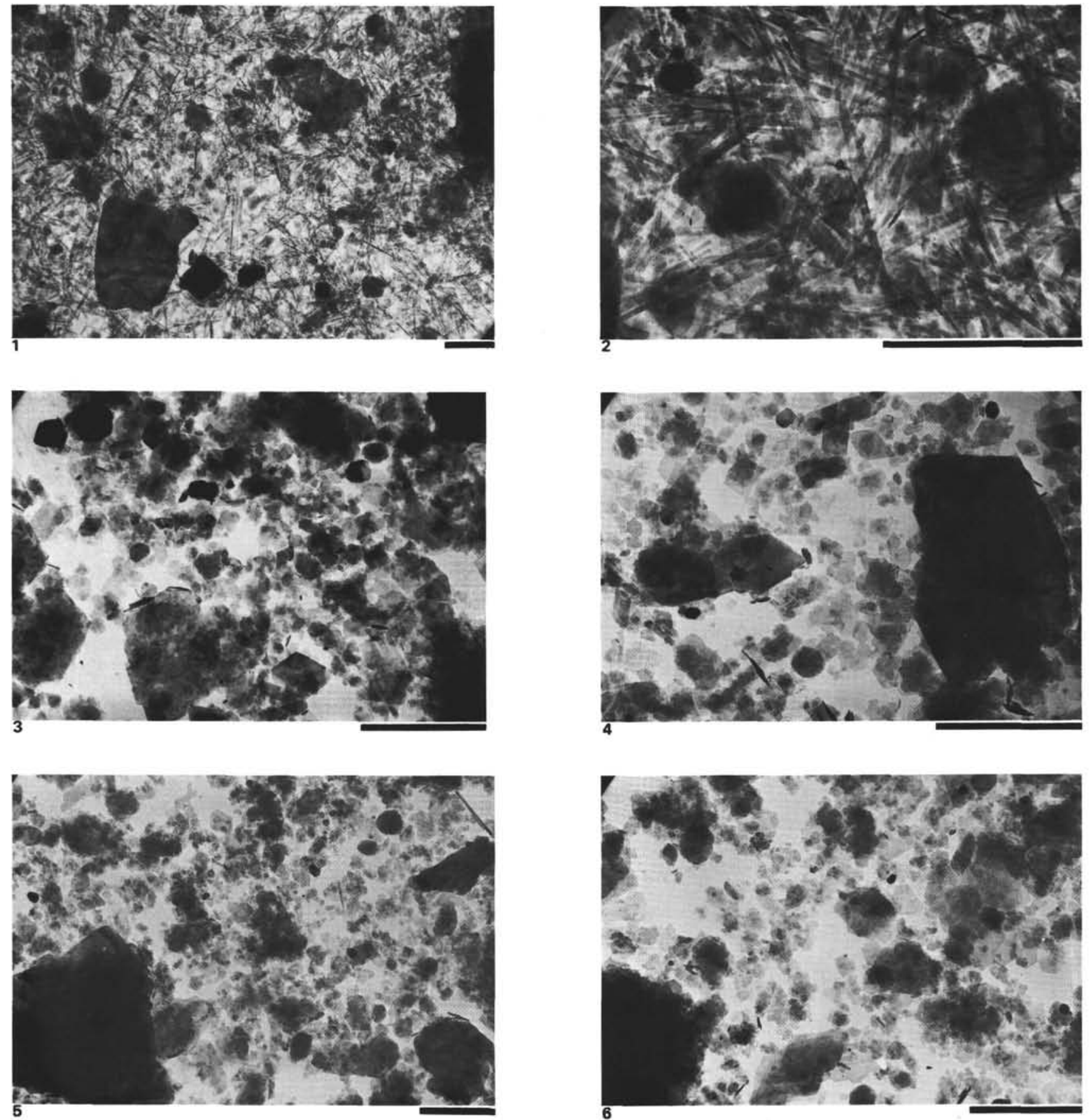

Plate 2. Electromicrographs. (Scale bar $=1 \mu \mathrm{m}$.) 1,2. Aptian, Sample 545-55, CC $17 \mathrm{~cm}$. Abundant palygorskite fibers, noticeable amounts of illite, smectite rare. 3,4. Lower Mesozoic sediments deposited above a sialic basement, Sample 547B-27-2, $110 \mathrm{~cm}$. Abundant illite, fairly abundant chlorite. 5,6. Lower Mesozoic sediments above a halite body, Sample 546-17-3, $89 \mathrm{~cm}$. Illite, chlorite, and corrensite, as well-shaped and polygonal sheets. 

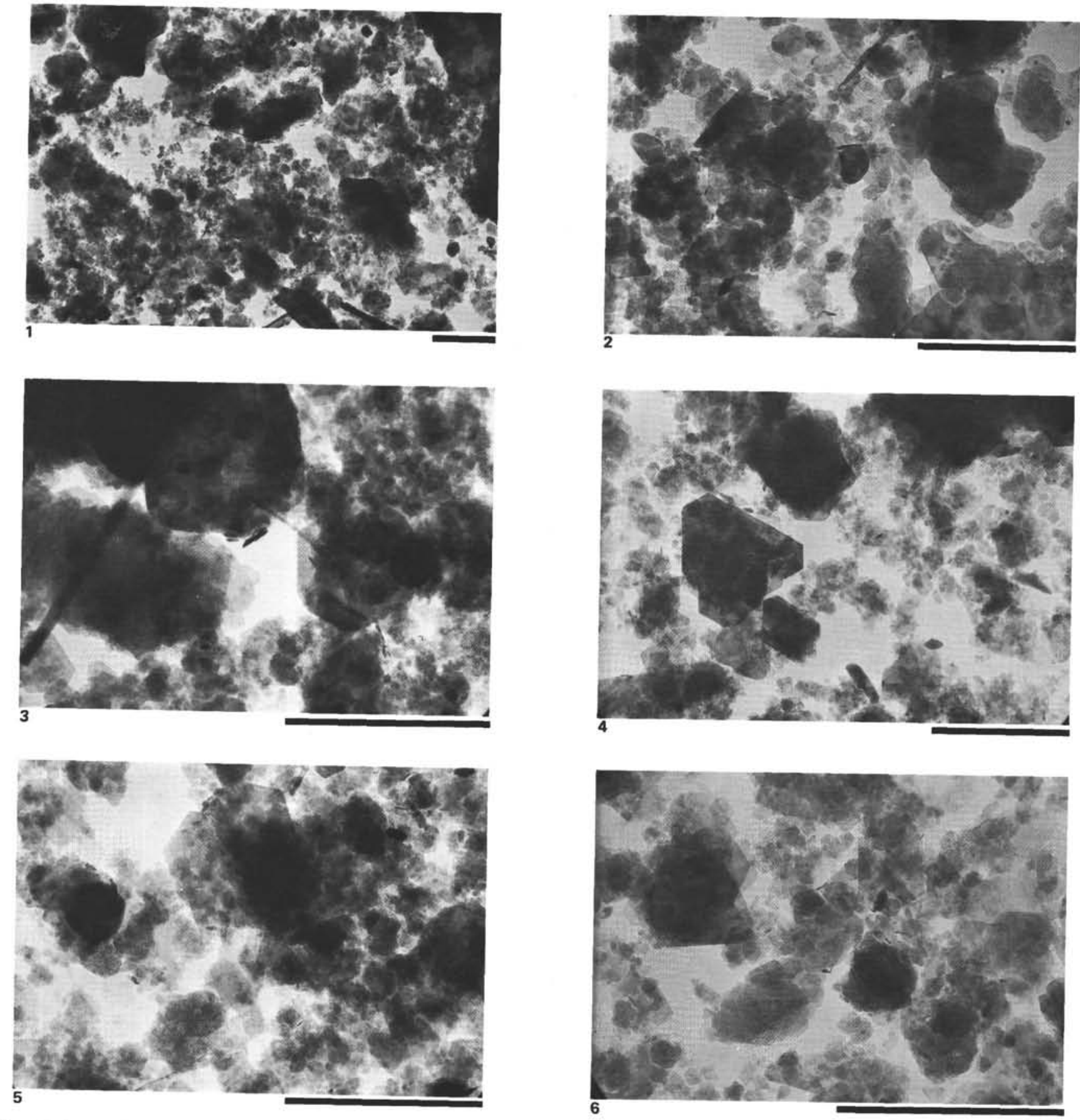

Plate 3. Electromicrographs. 1-3. Early Mesozoic, reddish clayey level in a halite gypsum body, Sample 546-18-3, $8 \mathrm{~cm}$. Very abundant chlorite polygonal phyllites, allewardite as broad and long laths (?), illite. 4-6. Early Mesozoic, greenish clay in a halite body, Sample 546-20-4, 30 cm. Abundant chlorite and illite, well-shaped and polygonal phyllites. 